УДК 94(571.1/.5).06/.07

ББК 63.3(253)51

\title{
Характер формирования и численность гарнизонов Колывано-Воскресенского ведомства во второй четверти XVIII в.
}

\author{
Д.С. Бобров
}

Алтайский государственный университет (Барнаул, Россия)

\section{The Activation and Number of Garrisons of the Kolyvano- Voskresensky Department in the Second Quarter of the $18^{\text {th }}$ Century}

\author{
D.S. Bobrov \\ Altai State University (Barnaul, Russia)
}

Публикация посвящена анализу динамики численности и характера формирования воинских гарнизонов Колывано-Воскресенских заводов во второй четверти XVIII в. в контексте регионального освоенческого и административно-политического процессов. Источниковую основу исследования составили подавляющей частью не введенные в научный оборот делопроизводственные материалы фондов Российского государственного архива древних актов.

Автор приходит к выводу о том, что на протяжении второй четверти XVIII в. шло планомерное увеличение численности гарнизонов КолываноВоскресенских заводов, состоявших как из регулярных, так и иррегулярных частей. Вопрос охраны производственных предприятий регулировался в рамках управленческого треугольника «гражданские власти - частновладельческие, а затем ведомственные кабинетские структуры - военные власти», где воеводы Кузнецкого уезда односторонне и малорезультативно стремились сохранить свое административное влияние на складывавшееся горное ведомство, а динамика насыщения воинскими подразделениями не столько увязывалась с расширением значимости производственного комплекса, сколько становилась реакцией на военные акции кочевников в приграничной зоне.

Ключевые слова: гарнизоны, гражданское управление, воеводы, Колывано-Воскресенское ведомство, А. Демидов, приказчики, Кузнецкий уезд.

DOI 10.14258/izvasu(2019)5-03

Феномен Колывано-Воскресенского производственно-территориального комплекса [1, с. 13-32] не одно десятилетие будоражит умы историков-сибиреведов. Между тем специальных работ, посвященных первоначальному периоду, времени при-
The publication is devoted to the analysis of the dynamics of the number and composition of military garrisons of Kolyvano-Voskresensky enterprises in the second quarter of the $18^{\text {th }}$ century within the framework of the regional administrative and political processes. The main source of this research paper consists of unintroduced into scientific use and materials of funds of the Russian State Archives of Ancient Acts.

The author comes to the conclusion that during the second quarter of the $18^{\text {th }}$ century there was a systematic increase in the number of garrisons of the Kolyvan-Voskresensky factories, consisting of both regular and irregular parts. The issue of production works protection was located in the framework of the management triangle "civilian authorities privately owned, and then departmental structures of the Cabinet - the military authority", where the voivodes of Kuznetsk Uyezd unilaterally and ineffectively tried to protect their administrative influence on the emerging mining department, and the military formation dynamics was not so much linked to the increased importance of the production complex, as it became a reaction to military actions in the border area.

Key words: garrisons, civil administration, voivodes, Kolyvano-Voskresensky department, A. Demidov, bailiffs, Kuznetsk Uyezd. надлежности предприятий Акинфию Никитичу Демидову, в последнее время становится все меньше, что связано с освоением специалистами доступной для изучения источниковой базы и утвердившимся 
в научной среде представлением о том, что ведущие аспекты нашли своего исследователя.

Сооружение Колыванского завода привело к существенному изменению политической ситуации на юге Западной Сибири. Если до этого ключевая роль в административном «присмотре», курировании освоения бассейнов Алея и Чарыша принадлежала томским воеводам, то с конца 20-х гг. XVIII в. - фактически сразу перешла к воеводам кузнецким. Во многом это связано с тем, что «ведомство Колывано-Воскресенского завода», несмотря на восприятие некоторыми современниками ${ }^{1}[1$, с. 112 , 115-116; 2, с. 61-62], не было выведено из уездной системы [3, с. 48], а сами заводы, хотя часто и именовались «томскими» [4, с. 116-117], однако большая часть их территории относилась к Кузнецкому уезду. При этом перманентное расширение площади, производственных мощностей и влияния колыванского комплекса на административную повестку неизбежно приводило к соприкосновению частновладельческих структур А.Н. Демидова с местными органами гражданского управления - кузнецкими воеводами. Правда, берг-привилегия, полученная горнозаводчиком, в значительной степени выводила первые из прямого подчинения вторым, образовав своеобразный вариант административной автономии. Тем не менее задача охраны промышленных предприятий, достаточно быстро ставшая едва ли не центральным и во многом системообразующим аспектом взаимоотношений разноотраслевых управленческих структур, вплоть до середины 40-х гг. XVIII в. ложилась на плечи в основном гражданских и лишь отчасти военных властей.

В историографии к настоящему времени реконструированы фундаментальные аспекты освоенческих и административно-политических процессов на юге Западной Сибири в XVIII в., однако вопрос формирования гарнизонов демидовских владений на Алтае, в том числе и его количественный аспект, до сих пор остаются в тени исследовательского интереса. Отдельные, но важные сведения о численности казаков, привлекавшихся для охраны Колыванского завода в период его строительства, содержатся в диссертации А.В. Контева [5, с. 86-87] и его известном очерке в соавторстве с В.Б. Бородаевым [6, с. 16-22]. Ставшая хрестоматийной работа этих авторов «У истоков истории Барнаула» делает акцент на выборе мест и обстоятельствах строительства первых предприятий, а также фиксации этих объектов на чертежах и картах $[4$, с. 60-171], лишь кратко упоминая о «приписных казаках» и рассматривая их

\footnotetext{
1 «Ведомство Колывано-Воскресенского завода» на российских картах середины 30-х - середины 40-х гг. XVIII в. изображалось в качестве обособленной административной единицы наряду с Кузнецким и Томским уездами.
}

в качестве особых формирований из приписных крестьян [4, с. 151]. Специалисты по истории казачества А.Р. Ивонин, а также Д.В. Колупаев применительно ко второй четверти XVIII в. приводят единственное, однако не поддающееся проверке, упоминание ${ }^{2}$ о том, что после набега казахов в 1728 г. «была присылка казаков из Кузнецка и Тары числом до 300 человек» [7, с. 36-37; 8, с. 16]. Схожий характер имеет монография А.А. Малолетко и А.М. Малолетко, где для XVIII в. дается краткий обзор состояния регулярных и иррегулярных войск на юге Западной Сибири [9]. Литература, посвященная администрированию Колывано-Воскресенского комплекса, сосредотачивается главным образом на складывании ведомственного аппарата управления, в результате чего в ней содержатся единичные сведения по воинским подразделениям округа [1, с. 45-72; 3 , с. $44-70 ; 10 ; 11]$. Исключением из этого ряда является исследование А.А. Пережогина, в котором достаточно полно раскрыта организация охраны колывано-воскресенских предприятий, однако уже после их передачи под управление Кабинета ${ }^{3}$, т.е. с 1747 г. [12, с. 89-110, 134-155]. В монографии А.В. Дмитриева, посвященной истории регулярных армейских частей Сибири XVIII в., реконструированы контингенты, кадровый состав и материальное обеспечение военных, но вопрос охраны КолываноВоскресенских заводов также не нашел широкого отражения [13].

В связи с этим целью текущей публикации является анализ динамики численности и характера формирования воинских гарнизонов колывано-воскресенских предприятий во второй четверти XVIII в. в контексте регионального освоенческого и административно-политического процессов. Источниковую основу исследования составили подавляющей частью не введенные в научный оборот делопроизводственные материалы фондов 248 (Сенат и его учреждения), 517 (Кузнецкая воеводская канцелярия) Российского государственного архива древних актов, а также «Описание Кузнецкого уезда...» Г.Ф. Миллера и отдельные археографические памятники, опубликованные в «Материалах для истории Сибири» Г.Н. Потанина. Специфика фондообразования документов первой половины XVIII в. обусловливает мозаичность и определенную относительность сведений о штате и численном составе укреплений Колывано-Воскресенского ведомства. Во-первых, следует учитывать слабую степень сохранности материалов при их отложении (полная или частичная утрата того или иного документа из-за пожара в региональных архивах, а так-

${ }^{2}$ Публикации в этом месте не содержат ссылки на источники.

${ }^{3}$ Кабинета Его Императорского Величества. 
же действия иных факторов). Во-вторых, реконструкцию осложняет и установившийся в первой половине - середине XVIII столетия характер учета войск, располагавшихся в пределах того или иного оборонительного объекта. Номинально являясь формально-строгим, в реальности он не позволяет с абсолютной уверенностью установить точное количество казаков, солдат или офицеров, находившихся в конкретной округе, что связано как с их плановыми «годовальными» командировками, так и с экстренными отправками («службами») в близлежащий район, уездный или губернский центр. B-третьих, в первой половине XVIII в. в условиях дефицита воинских команд региональные и местные власти активно практиковали привлечение для охраны объектов дополнительных иррегулярных частей на экстраординарной основе («верстание выписных казаков»): в случае военной опасности в службу временно верстались находившиеся в текущей или соседней округе беломестные казаки, отставные солдаты, крестьяне и разночинцы, что, в свою очередь, далеко не всегда находило необходимое отражение в документах.

Сразу после серии российских экспедиций конца 1710-х гг. в двух ведущих районах междуречья Оби и Иртыша властями стали практиковаться отличные друг от друга способы насыщения крепостных (острожных) гарнизонов: в Верхнем Прииртышье регулярными войсками, в Верхнем Приобье - иррегулярными частями.

Колыванский завод оказался фактически зажат между этими областями, в полной мере не относясь ни к одной из них, в результате чего подходы к организации его охраны выстраивались параллельно с развертыванием строительства самого предприятия. Берг-привилегия А.Н. Демидову определила, что задача формирования гарнизонов целиком должна ложиться на плечи гражданских региональных и местных властей, а на заводчика - только содержание военных команд [6, с. 16]. Указ Сената изначально лишь в общей форме санкционировал отправку на возводившийся Колыванский завод войск для «обереговой службы». С одной стороны, доношение руководившего работами Никифора Герасимовича Клеопина о вооруженном выступлении крестьян показывает, что уже в 1729 г. охрана осуществлялась ротами Московского и СанктПетербургского полков, а также «горной» ротой $[6$, c. 41-42]. С другой стороны, с близлежащих острогов и слобод Кузнецкого уезда перебрасывали группы служилых людей. Так, из Белоярской крепости в годы строительства первого медеплавильного предприятия посылали чуть более 25 казаков из 60 человек, несших обереговую службу, что вызывало недовольство в служилой среде [5, с. 87; 6, с. 16-17, $34,37]$. Таким образом, с самого начала существова- ния Колывано-Воскресенского комплекса его оборона осуществлялась на основе сочетания способов пополнения крепостных гарнизонов одновременно иррегулярными (служилыми людьми, которые ротировались по принципу годовальщиков в среднем раз в полгода или год) и регулярными воинскими частями.

Однако эти меры не уберегли строившееся предприятие от значительной по своим масштабам агрессии кочевников. В 1728 г. кузнецкий воевода Петр Нефедеев доносил сибирскому губернатору: «набежав неприятельские воинские люди в Кузнецком уезде на оные Демидовы Колыванские медные заводы, и отогнали триста семьдесят одну лошадь, и дву[x] человек ранили копьями, и от часовых пяти человек пять лошадей отбили» [6, с. 18; 14 , л. 610об.]. Следствием этого явилось оставление Н.Г. Клеопиным и всеми подчиненными ему людьми (включая присланных для обеспечения безопасности казаков) недостроенного завода, а также его незначительных укреплений и перемещение в административную округу Белоярской крепости [6, с. 19; 14, л. 610об.].

Раздраженный негативным развитием событий и вынужденный ответствовать перед Сенатом сибирский вице-губернатор Иван Васильевич Болтин принял решение разделить нагрузку охраны колывано-воскресенских предприятий между Томской и Кузнецкой канцеляриями: «дабы в произвождении тех заводов остановки какой не произошло... и служилым и работным людям быть при тех заводах неотлучно... и того им воеводам (томским и кузнецким. - Д.Б.) смотреть накрепко, дабы тем заводам от неприятельских людей... разорения не учинилось» [14, л. 614-614об.]. Кроме того, сенатским указом П. Нефедееву строго предписывалось контролировать местонахождение Н.Г. Клеопина и обеспечивать его безопасность.

Установленное расписание 1728 г. предполагало наличие в распоряжении Колыванской конторы ежегодно сменявшихся 60 конных казаков, 40 из которых присылали из Томска, а 20 - из Кузнецка [15, л. 38-39]. Однако порубежный характер Колывано-Воскресенского комплекса, удаленность его от Томска провоцировали массовое недовольство в среде служилых людей. Это вылилось в подачу коллективной челобитной от томских казаков на имя И.В. Болтина с требованием прекратить их посылки для охраны Колыванского завода.

Не желая раздувать конфликты в среде служилых людей и руководствуясь на первый взгляд рациональными основаниями, «а оные Демидова заводы к Кузнецку в близости, а от Томска в дальном расстоянии», И.В. Болтин 9 июля 1730 г. приказал «посылать на те (Колыванские. - Д.Б.) заводы для обережения от неприятельских людей кузнецких служилых людей... по шестидесят человек с пе- 
ременою» [15, л. 31об.-32]. Доводы, представлявшиеся вице-губернатором в качестве обоснования такого решения, выглядели по меньшей мере спорными: якобы служилые люди из Кузнецка не использовались для несения охраны в острогах и в сравнении с томскими служилыми были задействованы откровенно слабо. Такой тезис явно противоречил действительности ${ }^{4}$. Кроме того, губернаторский указ предусматривал в случае возрастания риска набега на предприятия увеличение количества кузнецких казаков до 100 человек [15, л. 32].

Уездный администратор П. Нефедеев стремился различными путями саботировать посылки служилых из Кузнецка. Во-первых, он откровенно медлил со сменой команды и до последнего держал Колыванскую контору в неведении не только относительно даты этого события, но и вовсе не счел нужным информировать заводских приказчиков о принятом И.В. Болтиным решении. Во-вторых, видимо, именно с подсказки воеводы кузнецкие служилые люди составили коллективную челобитную, в которой с высокой степенью точности приводили цифры командированных в различные районы Кузнецкого уезда, а в качестве главного аргумента указывали на то, что «... Томск между другими городами обстоит в средине и безо всякой опасности, а Кузнецкой город в крайнем месте» $[15$, л. 33-33об.]. Обращение откровенно преследовало цель восстановить существовавшую ранее практику организации охраны колыванских предприятий.

Другим источником информации о принятом губернаторском указе для частновладельческих управителей могла стать Томская канцелярия. Однако воевода А. Каратьев уведомил Колыванскую контору лишь о том, что «велено томских служилых отпустить, а требовать из одного града Кузнецка» $[15$, л. 37oб.]. При этом он даже не сообщил точного количества иррегулярной команды, которую отныне должны были посылать из соседнего административного центра для охраны предприятий.

Управители А.Н. Демидова, оказавшиеся в сложной ситуации и крайне слабо представлявшие конкретные аспекты транслировавшейся сверху доктрины, могли лишь вежливо поторапливать кузнецкого воеводу. В доношении от 26 декабря 1730 г. приказчик Никифор Семенов настоятельно просил главу уезда выделять по 40 человек в зимнее и по 100 в летнее время для охраны производства. Иными словами, не владея полной информацией, Н. Семенов пытался по умолчанию экстраполировать на кузнецких служилых людей расписание казаков, присылавшихся ранее из Томска, в отношении 1:1, хотя губерна-

\footnotetext{
${ }^{4}$ К этому времени в Верхнем Приобье кузнецкие служилые люди исключительно собственными силами обеспечивали охрану Бийской и Белоярской крепостей, Бердского острога, Мунгатского станца и других объектов.
}

торский указ предполагал отправку на охрану именно 60 человек.

Осознавая, что прибытия казаков из Кузнецка даже в соответствии с максимальной квотой может быть недостаточно для нормального функционирования охраны предприятий, демидовские управители на свой страх и риск, без каких бы то ни было нормативных оснований, дополнительно просили воевод командировать еще 100 человек [15, л. 37об., 39об.].

В итоге сменивший П. Нефедеева на посту воеводы Степан Степанович Зиновьев 2 января 1731 г. приказал направить в Колыванский завод 40 казаков в полном соответствии с требованиями частновладельческой конторы [15, л. 40], хотя это лишь частично реализовывало предписания губернаторского указа. Дальнейшие просьбы демидовских приказчиков о посылке в летнее время дополнительных команд удовлетворялись частично: вместо увеличения численности казаков до 100 человек воевода дополнительно отправлял лишь 20 служилых людей, «довыполняя» тем самым требования вышестоящего циркуляра [15, л. 42-43]. К середине 30-X гг. XVIII столетия ситуация, видимо, несколько сгладилась и стабилизировалась, что связано с появлением стационарного регулярного воинского гарнизона крепости Колыванского завода [5, с. 87], который, по сведениям Г.Ф. Миллера, приведенным в «Описании Кузнецкого уезда...», дополняли 100 кузнецких казаков [16, с. 27].

Тем не менее проблемы с организацией системы охраны производства ставили колыванских управителей перед нелегкой дилеммой: как организовать оборону при перманентно увеличивавшемся территориальном охвате производственного комплекса и возраставшем в течение конца 20-40-х гг. XVIII в. потоке транзитных торговых караванов из Джунгарского ханства. Иностранные торговцы, ощущая определенную привилегированность своего статуса, не гнушались воровством сена у заводских работников и даже открытыми разбоями. При этом робкие попытки находившихся на «обереговой службе» служилых людей ответить или хоть как-то пресечь противоправные действия, вызывали острое недовольство заграничных купцов. Последние постоянно угрожали жалобами джунгарскому хану и переводом конфликта на уровень межгосударственного. Всю сложность и неоднозначность складывавшейся ситуации, а также растерянность частновладельческой администрации в одном из своих доношений подчеркнул демидовский приказчик Илья Харитонов, просивший кузнецкого воеводу «дабы де соблаговолено было от таких их обид и нападок оборонить, и, как с ними в таких непотребствах поступать, о том требовано указу» $[17$, л. 16 об.]. 
На протяжении конца 20 -х - начала 40 -х гг. XVIII в. не существовало единой линии Кузнецкой канцелярии и в отношении возможности привлечения посылавшихся для охраны предприятий служилых людей к заводским работам: позиция воевод очень сильно зависела от их личных взглядов и субъективного видения ситуации. Если С.С. Зиновьев в свое время подчеркивал, что «кроме надлежащих караулов, работать при тех заводах оных их посланных ис Кузнецка служилых людей не принуждать» [15, л. 40-41]; то спустя всего лишь несколько лет его преемник Артем Федорович Бартенев в переписке с демидовскими приказчиками намекал на допустимость использования кузнецких казаков в качестве рабочей силы при строительстве амбара для хранения соли на Колыванском заводе [18, л. 5-5oб.].

Ощутимые изменения в организации гарнизонов колывано-воскресенских предприятий произошли во второй половине 30-х - середине 40-х гг. XVIII в. После создания в Сибири Новоучрежденного драгунского полка $[13$, с. 98-108] в приграничные районы на юго-западе Кузнецкого уезда достаточно оперативно были переброшены три роты. Руководство подразделениями, изначально дислоцировавшимися в Бийской и Белоярской крепостях, а также Малышевой слободе, осуществлял единый войсковой «командир» в звании капитана или майора, который подвергался периодической ротации5. После разорения калмыками Чагырского рудника в конце 1744 г. [19, с. 54] командир «кузнецких» рот капитан Василий Соколов получил перевод в окрестности колыванских предприятий на постоянную основу [20, л. 2-4, 34, 41-42 об., 45]. Вместе с ним была переброшена команда, составлявшая внушительную часть регулярных войск Верхнего Приобья. Согласно одному из рапортов его подчиненного поручика Осипа Свешникова к началу 1745 г. при заводах находилось 66 драгун, по одному капитану6, поручику, подпрапорщику, по три капрала, барабанщика, а также один денщик и два писаря, т.е. в общей сложности 78 военных7. При этом среди перечня командированных служилых людей не содержалось упоминаний об отправленных в Колыванское ведомство [20, л. 25-27].

В данном случае можно говорить о явной неточности рапорта, поскольку в изменившейся системе формирования гарнизонов производственного комплекса иррегулярные войска сохранились. На это указывает ряд обстоятельств. Прежде всего фрагмент поданного в июне 1745 г. доношения прапорщика Белоярского «фарпоста» Максима Попова, в кото-

\footnotetext{
${ }^{5} \mathrm{C} 1738$ по 1744 г. командиры «кузнецких» рот располагались в окрестностях Бийска.

${ }^{6}$ Имеется в виду сам Василий Соколов.

${ }^{7}$ Скорее всего, речь шла только о военных из Новоучрежденного полка.
}

ром сообщалось о требованиях В. Соколова «выслать в Колывань ис томских казаков в двух человек на место болных томских казаков» $[21$, л. 10]. Таким образом, видимо, в результате усложнения военнополитической ситуации в Верхнем Прииртышье и, как следствие, необходимости увеличения числа оборонцев была восстановлена практика посылок томских служилых людей на колывано-воскресенские предприятия. Фактически одновременно с этим кузнецкий воевода Яков Мирович констатировал наличие в округе заводов 53 конных и 43 пеших казаков, регулярно направляемых из возглавляемого им уезда [22, л. 24об.-25]. С одной стороны, это позволяет оценить условное количество томских казаков на колыванских производствах: если ведомственные документы Кабинета показывают, что в середине 40-х гг. XVIII в. при заводах находилось 147 казаков [9, с. 114], то за вычетом кузнецких, численность командировавшихся из Томска следует считать равной приблизительно 50. С другой стороны, необходимо констатировать сохранение установленной фактически еще в начале $30-\mathrm{x}$ гг. столетия нагрузки на кузнецких казаков по охране Колыванского комплекса. Однако корпус служилых людей уезда за прошедшее десятилетие значительно сократился, охрану самого Кузнецка осуществляли лишь чуть более сотни казаков, 20 из которых были верстаны из коренного населения (абинских татар) [22, л. 27-27o6.]. Вследствие этого Я. Мирович просил возглавлявшего войска Сибирских линий Христиана Христиановича Киндермана сократить количество прикомандированных из Кузнецка более чем вдвое: «не позволит ли Ваше Высокопревосходительство от Колыванских заводов приказать выслать, хотя 6 половинное число здешних кузнецких, которые там [обретаются]» $[22$, л. 250б.]. В качестве аргументов воевода упоминал необходимость того, чтобы «в Кузнецку, яко в пограничном городе небезопасной, полной штат казаков состоял», а также то обстоятельство, что в окрестностях заводов имелась «регулярная команда и еицкие ${ }^{8}$ казаки» [22, л. 25 об.-26]. Кроме того, следует учитывать, что в результате волны приписок к колыванским предприятиям 1738-1742 гг. в производственный район из округи Белоярской слободы были переселены некоторые проживавшие там беломестные казаки, которые, очевидно, самым активным образом привлекались к охране заводских комплексов.

Количество регулярных военных в окрестностях демидовских предприятий в начальный период принудительного выкупа последних согласно «Экстракту о числе форпостов, крепостей, людей в них...» составляло 270 человек, в том числе 56 рядовых [23, с. 17-18]. Таким образом, общая суммар-

\footnotetext{
${ }^{8}$ Видимо, яицкие, т.е. с р. Яик.
} 
ная численность регулярных и иррегулярных частей, дислоцировавшихся в производственном районе, в 1744-1745 гг. превысила 400 человек.

Официальное штатное расписание войск складывавшегося Колывано-Воскресенского округа было закреплено лишь решением состоявшегося в январе 1748 г. в Тобольске «консилиума» с участием Х.X. Киндермана, сибирского губернатора Алексея Михайловича Сухарева и начальника КолываноВоскресенских заводов Андрея Венедиктовича Беэра. Охрану Змеиногорского рудника, Барнаульского и Колыванского заводов должны были осуществлять 250 драгун, 600 солдат и 850 казаков [12, с. 89], т.е. в общей сложности более полутора тысяч военных, что в несколько раз превосходило численность аналогичных гарнизонов в начале и даже середине 40 -х гг. столетия.

В целом на протяжении второй четверти XVIII в. следует констатировать устойчивую тенденцию к увеличению численности гарнизонов колывано-воскресенских предприятий. Региональные власти, постепенно осознав уязвимость пополнения дислоцировавшихся вблизи производств воинских команд в основном иррегулярными соединениями, стремились к усовершенствованию соответствую- щих практик, в том числе за счет их усложнения. В свою очередь, это привело к ранней интеграции производственного района в гораздо более широкий процесс административных преобразований, протекавших на юге Западной Сибири уже со второй половины 30-х гг. XVIII в.

В результате вопрос охраны производств выходил за рамки только складывавшейся вертикали управления колывано-воскресенскими предприятиями и регулировался в рамках административного треугольника «гражданские власти - частновладельческие, а затем ведомственные кабинетские структуры - военные власти», где кузнецкие воеводы односторонне и малорезультативно стремились удержать складывавшееся горное ведомство в орбите своего административного влияния, а сохранение нагрузки по несению «обереговой службы» в Колыванском комплексе значительным образом и во многом объективно тяготило корпус служилых людей уезда. При этом динамика комплектования воинских подразделений заводов увязывалась не столько с усилением политического авторитета и экономической мощи производственного района, сколько становилась реакцией на военные акции кочевников в приграничной зоне.

\section{Библиографический список}

1. Соболева Т.Н., Афанасьев П.А., Кухаренко А.Е., Бобров Д.С. Эксплуатация природных ресурсов Алтая императорским Кабинетом как фактор развития российской монархии (XVIII - начало XX в.). Барнаул, 2012.

2. Бородаев В.Б., Контев А.В. Исторический атлас Алтайского края: картографические материалы по истории Верхнего Приобья и Прииртышья (от античности до начала XXI в.). Барнаул, 2006.

3. Контева О.Е., Контев А.В. Территория Алтайского края в общегражданской и ведомственной системах управления (XVIII в.) // История Алтайского края. XVIII-XX вв.: научные и документальные материалы. Барнаул, 2004.

4. Бородаев В.Б., Контев А.В. У истоков истории Барнаула. Барнаул, 2000.

5. Контев А.В. Становление и развитие горно-металлургического производства в Западной Сибири (конец XVII - первая половина XVIII в.) : дис. ... канд. ист. наук. Барнаул, 1997.

6. Бородаев В.Б., Контев А.В. Как возникла Колывань // Колывань: История, культура и искусство сибирской провинции России. 1728-1998. Барнаул, 1998.

7. Ивонин А.Р. Городовое казачество Западной Сибири на Колывано-Воскресенских заводах в XVIII в. // Охрана и использование памятников истории горного дела и камнерезного искусства Алтайского края: тезисы докладов краевой конференции. Барнаул ; Змеиногорск, 1986.

8. Ивонин А.Р., Колупаев Д.В. Казаки на Алтае в XVIIIXIX столетиях: исторические очерки. Барнаул, 2003.

9. Малолетко А.А., Малолетко А.М. Воинство Алтайского горного округа (1726-1917). 2-е изд. Томск, 2012.

10. Соболева Т.Н., Разгон В.Н. Очерки истории кабинетского хозяйства на Алтае (вторая половина XVIII первая половина XIX в.): управление и обслуживание. Барнаул, 1997.

11. Контева О.Е. Становление и развитие системы управления кабинетским горнозаводским ведомством в Западной Сибири: 1745-1798 гг. : дис. ... канд. ист. наук. Барнаул, 2005.

12. Пережогин А.А. Военизированная система управления Колывано-Воскресенского (Алтайского) горного округа (1747-1871 гг.). Барнаул, 2005.

13. Дмитриев А.В. Русская регулярная армия в Сибири (1725-1796): особенности военной службы на «восточной окраине» Российской империи в XVIII столетии. М. ; СПб., 2017.

14. Российский государственный архив древних актов (РГАДА). Ф. 248. Оп. 13. Кн. 725. Д. 131.

15. РГАДА. Ф. 517. Оп. 1. Д. 26. 
16. Миллер Г.Ф. Описание Кузнецкого уезда Тобольской провинции в Сибири в нынешнем его состоянии в сентябре 1734 г. // История Сибири. Первоисточники. Вып. VI: Сибирь XVIII в. в путевых описаниях Г.Ф. Миллера / изд. подг. А.Х. Элерт. Новосибирск, 1996.

17. РГАДА. Ф. 517. Оп. 1. Д. 91.

18. РГАДА. Ф. 517. Оп. 1. Д. 82.

19. Огурцов А.Ю. На Кузнецкой линии // Кузнецкая старина. Новокузнецк, 2007. Вып. 9.
20. РГАДА. Ф. 517. ОП. 1. Д. 293.

21. РГАДА. Ф. 517. Оп. 1. Д. 286.

22. РГАДА. Ф. 517. Оп. 1. Д. 302.

23. Материалы для истории Сибири / сост. Г.Н. Потанин // Чтения в Императорском обществе истории и древностей российских при Московском университете. М., 1867. Кн. 4. 